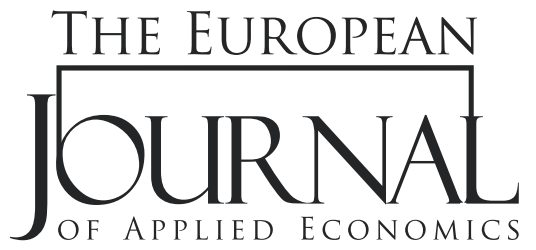

EJAE 2018, 15(1): 94-109

ISSN 2406-2588

UDK: $330.564: 614(6)$

DOI: 10.5937/EJAE15-16293

Original paper/Originalni naučni rad

\title{
INCOME-HEALTH NEXUS IN SUB-SAHARAN AFRICA: EVIDENCE FROM HETEROGENEOUS PANEL MODELS
}

\author{
Ibrahim Abidemi Odusanya ${ }^{1 *}$, Akinwande A. Atanda² \\ ${ }^{1}$ Department of Economics, Olabisi Onabanjo University, \\ Ago-Iwoye, Nigeria \\ ${ }^{2}$ Department of Economics and Finance, University of Canterbury, \\ New Zealand
}

\begin{abstract}
:
An attempt is made in this research to examine the relationship between income and health by testing the Absolute Income-Health Hypothesis (AIH). The study primarily focuses on 34 Sub-Saharan Africa (SSA) countries for the period of 2001-2016. The data for the study were mainly sourced from World Development Indicators (WDI) and the World Health Organization (WHO) Global Health Observatory Data Repository. Using heterogeneous slopes modelling set-up that incorporates series of non-stationarity, cross-section dependence, and group-specific trends, we failed to find evidence in support of the AIH. Our empirical outcome cast doubts on the robustness of previous studies that ignored such modelling attributes, while we deduced that methodology matters in analysing income-health nexus and testing the validity of the AIH for cross-section of countries. By contrast, we find income to be an insignificant determinant of health in SSA compared to health spending and improved sanitation.
\end{abstract}

\section{Article info:}

Received: January 17, 2018

Correction: March 18, 2018

Accepted: March 20, 2018

\section{Keywords:}

Health,

Income,

Sub-Saharan Africa,

Heterogeneous slope,

Cross-section Dependence

\section{INTRODUCTION}

Average households' health status is one of the barometers of population well-being, and is largely dependent on income level among other determinants. The relationship between income and health has generated some hypotheses and empirical conclusions. One of the leading predictions, Absolute Income-Health Hypothesis (henceforth, AIH) can be traced to Grossman (1972) model, and later on to Preston, (1975) both of whom state that wage increase can enhance health. The hypothesis suggests that health improves with average income but at a decreasing rate. This implies a curvilinear association between income and health. 
There is a plethora of empirical evidence on the validity of AIH, mostly documented for developed and high-middle income countries. The studies that confirm the validity are Qi (2012) for 19 OECD countries, Kuehnle (2014) for United Kingdom, and Ram (2005) for 51 US states. To the best of our knowledge, there is a dearth of research validating AIH for Africa, only few selected African countries are pooled with other developed and less developing countries. Studies in this regard include Qi (2012) that considered 34 non-OECD countries and Ram (2006) that pooled 26 OECD and 82 less-developed countries. On this basis, the precise relationship between income and health in Africa is unclear, especially in Sub-Saharan Africa (henceforth SSA) characterized by increasing absolute per capita income but coupled with deteriorating health status (see estimates from WHO, 2014).

It is very imperative to understand the relationship between income and health for two cogent reasons. Studying the relationship between income and health would offer better understanding on whether social differences in health status are attributable to poverty (or low income), or whether there is a socio-economic gradient in health status (implying that health status rises with each level of socio-economic or income status). Additionally, the investigation of the relationship between income and health will contribute to the debate on the diminishing returns of health with respect to income (Jusot 2006).

Recent developments in panel data econometrics have revealed that standard panel data estimators such as pooled ordinary least square (POLS), fixed effect (FE) and random effect (RE) estimators can be misleading ignoring heterogeneity (of observed and unobserved factors), cross-section dependence and non-stationarity (Ando and Bai, 2016; Eberhardt and Presbitero, 2015). Neglecting those attributes has severe implications on the standard estimators' biasness and consistency properties. To the best of our knowledge, our study is the first attempt to acknowledge the attributes and apply heterogeneous panel data estimators to test the validity of AIH for SSA.

The remaining part of this paper is divided into four sections. Section 2 deals with literature review while section 3 focuses on the data and the adopted methodology. Section 4 discusses the results from estimation while the last paragraphs provide conclusions of the study.

\section{LITERATURE REVIEW}

Earlier studies on the relationship between average income and health submitted that their association is concave. This implies that as average income increases, health status also increases. Later on, the increases will be at a decreasing rate after the point of inflexion, which is due to epidemiological transition (Omran, 2005). Epidemiological transition is the period when the patterns of disease change from infectious or contagious diseases (like cholera, chicken pox, tuberculosis, HIV/AIDS) to degenerative or non-communicable diseases (like cancer and cardiovascular diseases). This period has peculiarity of a burden of mortality comprising of the old rather than the very young people, while overall life expectancy will increase (Omran, 2005). During this period, the marginal effect of increases in absolute income falls to the extent that more variations in health are due to differences in income inequality. Therefore, as the level of per capita income increases, the effect of income inequality on population health becomes greater (Gravelle, Wildman, and Sutton, 2002). Rajan, Kennedy, and King (2013) also surmised that the positive relationship between average income and health discontinues once epidemiological transition sets in. 
An inextricable relationship exists between income and health in the health economics literature over a long period. The relationship between income per capita and life expectancy (a measure of health outcome) across countries for years 1900, 1930 and 1960 was found to be positive, with life expectancy varying more with income in poor countries than in rich countries (Preston, 1975). The correlation between income per head and life expectancy was 0.89 . This implies that 1 percent variation in income results in 89 percent variation in life expectancy. The study culminated into the famous 'Preston Curve' in which the regression line was fitted to data (having life expectancy on the y-axis and income on the $\mathrm{x}$-axis). In the same vein, the association between income and measures of health in the UK was found to be linear (except for very high and low income), both before and after controlling for selected socio-economic variables (Ecob and Smith, 1999). A doubling of income caused health to change by the same magnitude. It thus implies that increasing income is associated with improvement in health, but there are diminishing returns at higher levels of income.

Using data set involving self-perceived health and chronic illness as dependent variables with the sample made up of 28,023 individuals across the 17 autonomous regions in Spain, personal income exerted significantly and positively on health, with these effects diminishing at higher level of income (Karlsdotter, Martin and Gonzales, 2012). One percentage point in personal income caused 87.3 percent reduction in the probability of suffering from chronic illness. They used multilevel logistic regression models that allowed for the determination of the direct effect of the individual and group explanatory variables and the interactions between levels. The outcome of their study supports the absolute income hypothesis for both perceived health and chronic illness, and conforms to the findings emanating from most international and Spanish studies. It therefore suggests that richer populations do not improve their health with additional income as the poorer people do. In the study of the association of self-rated health with income dynamics among male employees in Japan, it was deduced that an individual's self-rated health was generally associated with short-term changes in income (Oshio,Umeda, and Fujii, 2013). Specifically, the survey focused on four annual income variables (i.e. current income, income in the previous year, average income and maximum income) and five income dynamic variables (i.e. increase and reduction in income from the previous year, increase and reduction in average income, and reduction in maximum income). They revealed that an individual's average and maximum income levels were irrelevant vis-à-vis self-rated health while no clear association was observed between longerterm changes in income levels and self-rated health. They reiterated that this finding could be attributed to the extremely homogeneous nature of their sample (consisting of only males, $74.6 \%$ of whom are graduates of college and $76.7 \%$ of them are regularly employed) while they also excluded people who had any interruption in their wage history (Oshio et al., 2013). Thus, income variables used in the study sample did not reflect substantial differences in educational attainment and occupational status, which are likely to have a close relationship with self-rated health independent of income. Importantly, they found a reduction in income, compared to the previous year, to be negatively associated with self-rated health. In a regression of under-five mortality rates on district level average income, income inequality, poverty gap and literary rate in India, infant mortality rates were found to be negatively associated with poor average income levels and positively associated with poverty at both state and district level (Rajan et al., 2013). A unit increase in average income resulted into 0.0028 reduction in mortality. In addition, linear regression models controlling average income and variation in some state-level variables showed that income inequality was not a statistically significant predictor of infant or under-five mortality rates. Similarly, the coefficient of average income was statistically insignificant after controlling poverty gap and literacy rates. 
Bloom and Bowser (2008) examined the relationship between income and life expectancy using data from 3,049 counties in 50 states in the US for the years 1970 and 2000 (including the District of Columbia). It involved the classification of counties to the Mississippi River Delta Region (where population health indicators are significantly lower than the rest of the US) and non-Delta region (where population health indicators are far better). The difference in health between the Delta and non-Delta regions in 1970 was due to $64 \%$ variation in income while the remaining $36 \%$ was attributed to the non-income factors. However, for 2000, non-income factors explained $77 \%$ disparities in health between the Delta and non-Delta counties while $23 \%$ of the variation was due to the non-income factors. Likewise, one percent increase in income per capita is associated with a 0.035 -year increase in life expectancy for Delta counties in 1970, a 0.032-year increase in life expectancy for Delta counties in 2000, a 0.035-year increase in life expectancy for non-Delta counties in 1970 and 0.038-year increase in life expectancy for non-Delta counties in 2000. Over time, non-income factors drove health particularly when epidemiological transition sets in. These non-income factors included dietary habits, smoking, occupational status, school enrolment and school curriculum (Bloom and Bowser, 2008).

Meanwhile, evidence supporting the absolute income hypothesis holds when probit regression was applied to micro data on the Chinese economy. The results showed a concave relationship between self-reported health status and per capita income, implying that additional income brought about greater improvement in the health of the poor than the rich ( $\mathrm{Li}$ and $\mathrm{Zhu}, 2006)$. A significant and $\mathrm{U}$ shaped relationship existed between self-reported health status and community-level income inequality. Thus, rising inequality tends to improve health when inequality is low and tends to harm health when inequality is above a certain level. In the same vein, individual income level has a considerably greater influence on health than neighborhood affluence in the US economy when Hierarchical Ordinal Logit models was applied to variables driving self-rated health (Wen, Browning, and Cagney 2003). This suggests that individual level poverty has a persistent noxious effect on health even with the potential benefits attached to residence in affluent neighborhood. To the contrary, income was associated with health in Canadian provinces whereas income inequality was significant with chronic health conditions (Safaei, 2007). Therefore, whatever the magnitude of the estimated health inequalities, ill health is mostly concentrated in the poor and low-income groups.

However, income, income inequality and other socio-economic measures accounted for seven-fold differences in the self-reported health of the elderly between the worst and the best provinces in China (Feng, Wang, and Li, 2012). They also deduced that for the poorest three quarters of their sample of 14,744 elderly individuals from 23 Chinese provinces, income brought about greater improvement in the health of the poor other than the rich, reflecting the concavity effect i.e. a curvilinear relationship between self-rated health and total family income. The study found odds of poor health to be three times greater for the elderly with the lowest income compared to those at the upper quartile. Meanwhile a strong correlation exists between the risk of death (measured via mortality rate) and income in France in a study involving classification of income into different quintiles. This strong relationship holds for all levels of income, despite controlling for occupational status. Every increase in equivalent taxable income was associated with significant reduction in risk of mortality (Jusot, 2006). A major dispersion of his findings to others is that a positive association exists between income and health even at higher levels of income. This is indeed contrary to the hypothesis of diminishing returns of income on health as reported by many of the authors that have tested the absolute income hypothesis. Pritchett and Summer (1996) used an instrumental variable estimator to analyze cross-country data spanning over 
twenty six years (1960-1985) to test the relationship between income and health, it was also deduced that increased income leads (causally) to improvements in health. Growth in mean income by 71 percent in the sampled countries culminated into 50 percent fall in infant mortality rate.

A positive but diminishing relationship between income and health was found for a cross-section of 75 developed and developing countries, thereby confirming the concavity (or non-linearity) of the health-income curve (Gravelle, Wildman, and Sutton, 2002). Therefore, they corroborated the proposition of the absolute income hypothesis. Contoyannis, Jones and Rice (2004) examined health dynamics, health and income using the British Household Panel Survey (BHPS) data. They disaggregated income into current and permanent income. They observed that current income only affected health status of man significantly, while it exerts no significant impact on health status of women. Jones and Wildman (2008) also investigated the relationship between income and health based on the British Household Panel Survey (BHPS) for men and women. Health status was measured using the self-assessed health (SAH), absolute income was measured by annual household income, while a measure of relative deprivation was also introduced as an independent variable. The pooled OLS, fixed effects and random effects models revealed a positive and significant relationship between income and health for both men and women, without the measure of relative deprivation in the model (Jones and Wildman, 2008). When the measure of relative deprivation is included in the model, the relationship was still significant and positive for men and women, but was not significant using the random effects estimator. It is however apt to note that the magnitudes of the coefficients are generally small, with large changes in income resulting in small changes in health.

Based on pooled 1990 and 2000 data for 51 states in the US with death rate (death per 100,000 populations) specified as the dependent variable, a significant negative relationship was found between income and death rate. An increase in personal income generally resulted in a more proportionate diminution in death rate for all the specified models. This implies that increases in income are associated with improvement in health status (Ram, 2005). A very strong positive correlation existed between income inequality and death rate, with poverty exerting negatively on health. On a study of six European countries and with data on individuals aged between 50 and 65, absolute income had a positive but quite modest effect on health after controlling for endogeneity (Theodossiou and Zangelidis, 2009). In another study to examine cross-country association between income and health for 108 countries (comprising 18 OECD countries and 90 LDCs), a very strong correlation exists between income and health (measured by infant mortality rate). Income exerted a significant negative effect on mortality for all the countries. When the less developed countries (LDCs) were isolated, poverty index ${ }^{1}$ had a positive relationship with infant mortality rate while income had a negative relationship with infant mortality (Ram, 2006). Meanwhile income inequality also had a positive relationship with the mortality rate. He inferred that income inequality other than poverty contributed more to infant mortality rate in the LDCs. Moreover, both income and GINI (a measure of income inequality) have larger effects in the LDCs, but the relative effect of GINI is stronger in the full sample (and thus in the DCs) while the marginal effect of income is stronger in the LDCs. This view was corroborated by Qi (2012), who found that the effect of absolute income is stronger in the LDCs. The detrimental effect of income inequality is largely obvious among the developed countries. By applying multilevel logistic regressions to 19 OECD and 31 non-OECD countries, the effect of GDP per capita on self- rated health was statistically significant for non-OECD countries (Qi, 2012). A unit increase in income caused 0.063 unit increase in self-rated

1 Poverty index is the percentage of population whose income is below the international poverty line of one PPP dollar per day (per person). 
health based on the entire sample. This reflects that absolute national wealth is more important for countries at the lower level of economic development (i.e. the non-OECD countries). The results from the study generally supported the absolute income hypothesis, and no significant detrimental effect of income inequality on individual health has been found. The findings also imply that when a country's distribution of income is more unequal, the gap in self-rated health widens between people at different deciles of household income and the poor suffered more deprivation in terms of health. French (2012) investigated causation between income and health for 13 OECD countries with the aid of Panel Analysis of Non-Stationarity in Idiosyncratic and Common Components (PANIC) model. One percent increase in income per capita caused 0.02 percent increase in life expectancy. Obviously, income improved health while health also exerted significantly on income. Rehnberg and Fritzell (2016) examined the longitudinal relationship between midlife income and mortality as well as late-life income for an ageing Swedish. For midlife ages (50-60 years), the association between income and mortality was curvilinear i.e. returns to health diminishes as income rises. As income increases, the hazard ratio of mortality decreases, especially for households with equivalised income of between 100,000 and 300,000 Swedish crowns (SEK). This group constitutes the largest proportion of the population. In the same vein, the relationship was curvilinear for those in the age bracket of 65-75 years. The results generally reveal the prolongation of the non-linear relationship between income and mortality into old age.

A number of studies have also examined the relationship between family income and child health for different countries in which they reported a positive association between family income and parentreported child health in the US, Australia, Canada and Germany. Aponey and Geoffard (2013) examined the income gradient in health across UK. The study found the emergence of the income gradient for children around age 2, while it was constant for children between ages 2 to 17 . However, no correlation existed between income and child's health at ages 0 -1. Using instrumental variable to examine the causal effect of family income on child health in the UK, income was found to have a significant but small causal effect on child health. Specifically, a positive association existed between family income and parent reported health (Kuehnle, 2014). Furthermore, various transmission mechanisms (housing, nutrition, medications, and behavioural problem of the child) through which family income affects child health were all found to be influential on the health of the children. Goode, Mavromanas and Zhu (2014) examined the effect of family income on child health in China. Family income exerted positively on child health via household sanitation conditions, parental health consciousness and nutrition intake. Family income exerted positively on height for age-z-score (HAZ) of children in ages 4-8, 9-12 and 13-17 at 1 percent level of significance except for ages 0-3. However, children from poorer homes were susceptible to chronic illnesses. The study confirmed the validity of the AIH. Nakaruma (2014) studied the relationship between parental income and child health in Japan. A significant existed between parental income and incidences of dental problems, asthma and hearing problems. In the same vein, income exerted a significant positive effect on health as $10 \%$ increase in income generally translated to 0.02 reductions in number of illness in Tanzania (Fichera and Savage, 2015). Daley (2017) investigated the effect of income transfer on health of families with young children. Income transfer improved mental health and life satisfaction irrespective of the structure of the family.

A synthesis of the reviewed empirical studies in Table 1 shows that larger number of these studies support the AIH while findings from others are to the contrary. It is quite apt to note that there is a relative dearth of studies investigating income-health relationship for SSA countries while the literature is replete with such studies for the developed economies, particularly the OECD-member countries. Thus, whether this theory actually holds in general, for all categories of economies, is a matter of continuing debate. 


\begin{tabular}{|c|c|c|c|c|c|c|c|c|}
\hline 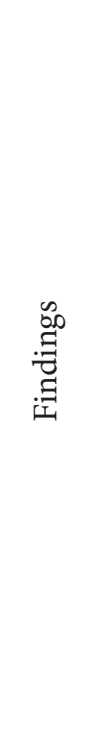 & 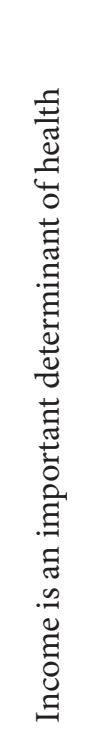 & 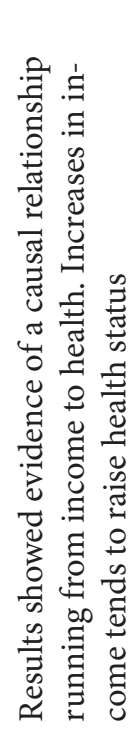 & 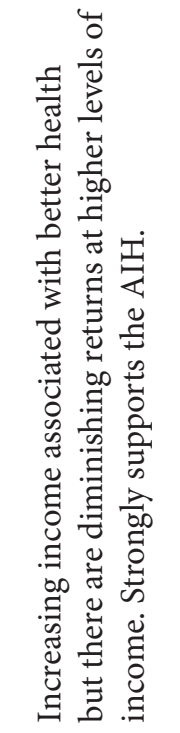 & 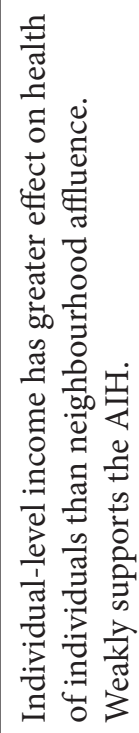 & 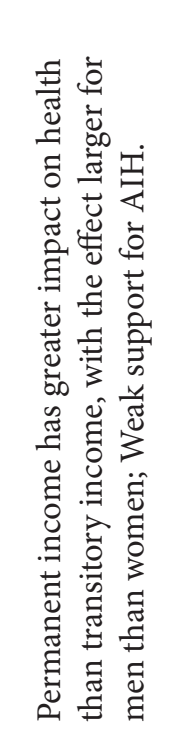 & 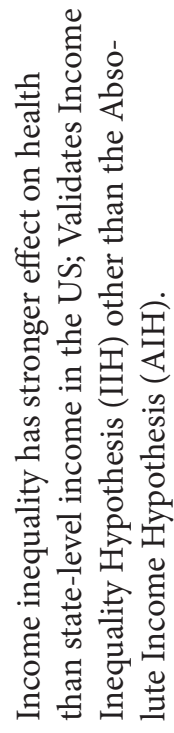 & 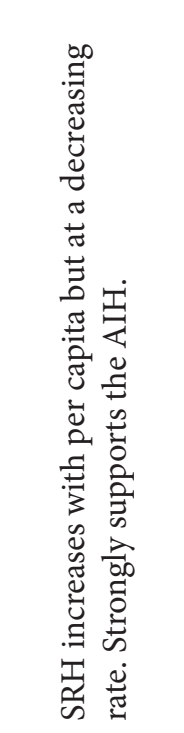 & 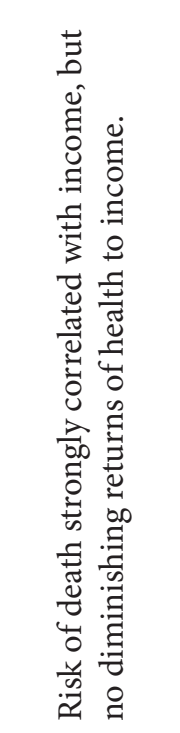 \\
\hline 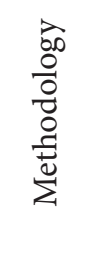 & 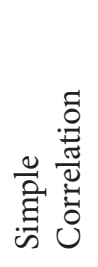 & 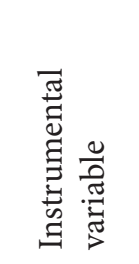 & 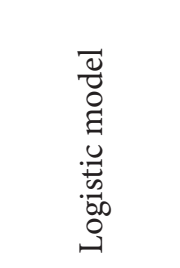 & 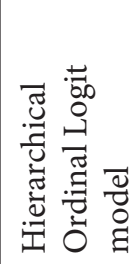 & 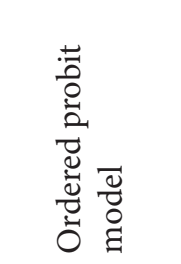 & 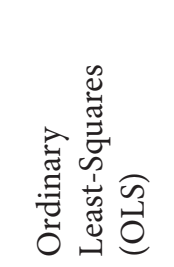 & 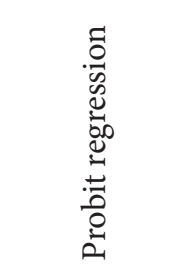 & 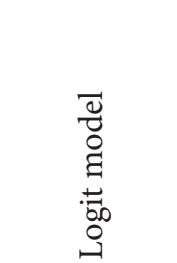 \\
\hline 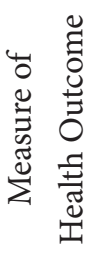 & 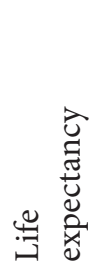 & 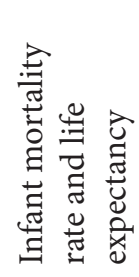 & 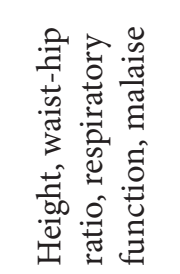 & 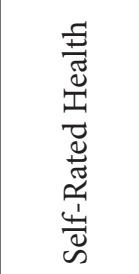 & 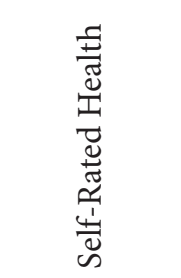 & 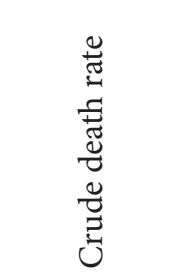 & 荵 & 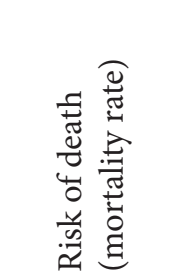 \\
\hline 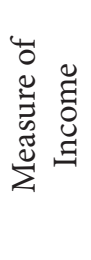 & 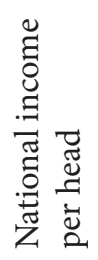 & 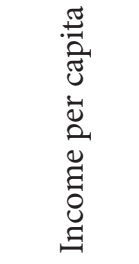 & 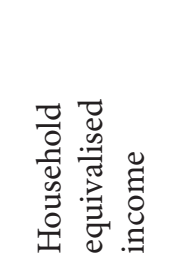 & 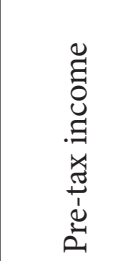 & 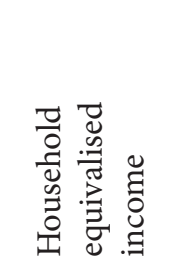 & 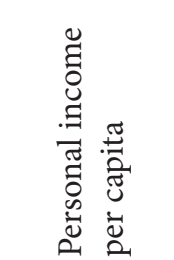 & 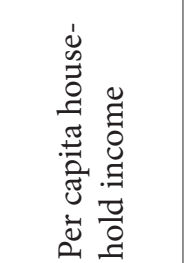 & 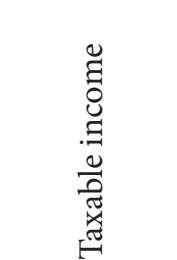 \\
\hline 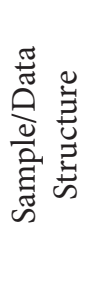 & 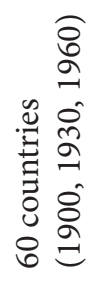 & 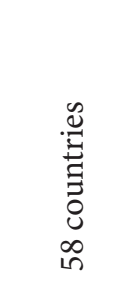 & 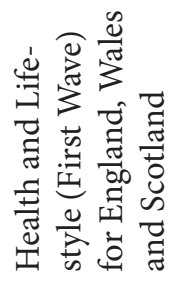 & 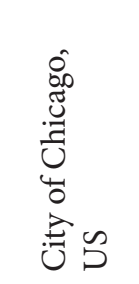 & 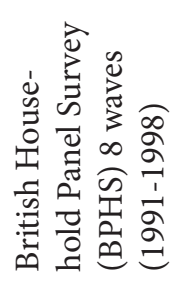 & 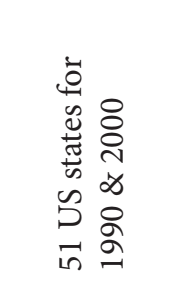 & 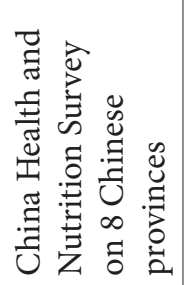 & 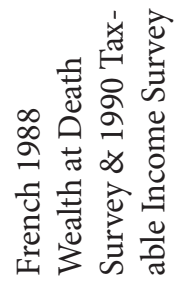 \\
\hline 胥 & 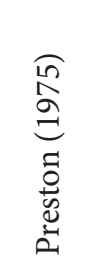 & 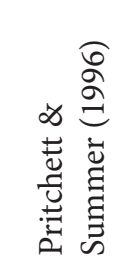 & 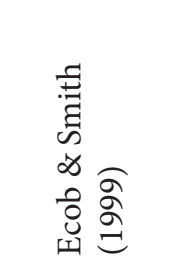 & 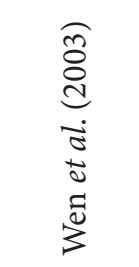 & 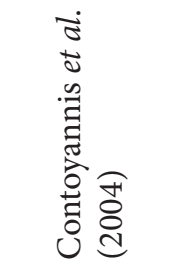 & 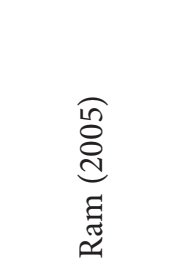 & 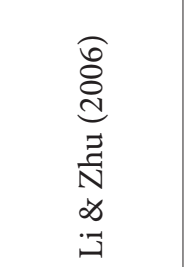 & 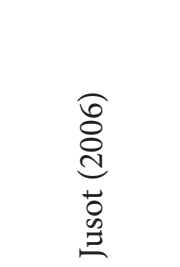 \\
\hline$\frac{Z}{n}$ & $\neg$ & $v$ & $m$ & F & in & 6 & $\Lambda$ & $\infty$ \\
\hline
\end{tabular}




\begin{tabular}{|c|c|c|c|c|c|c|c|}
\hline 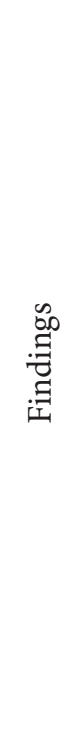 & 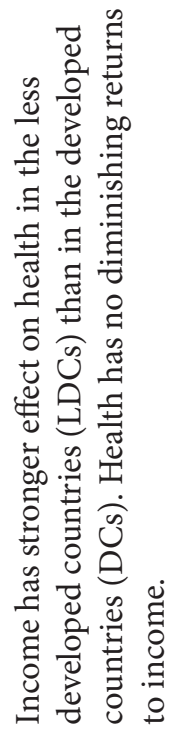 & 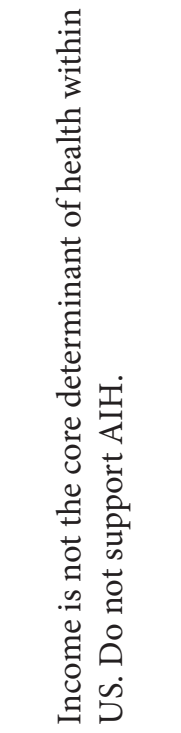 & 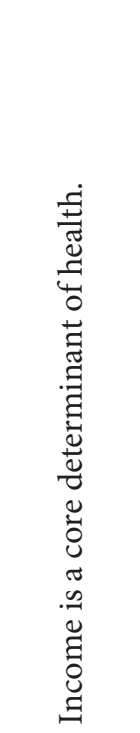 & 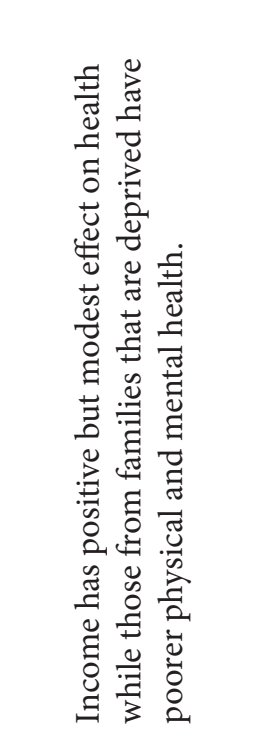 & 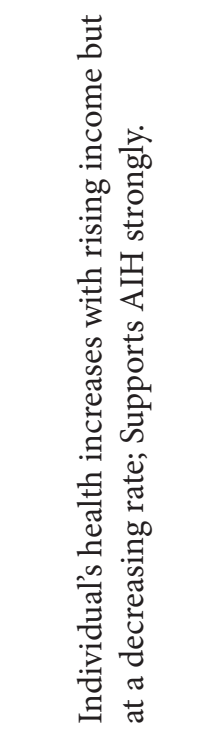 & 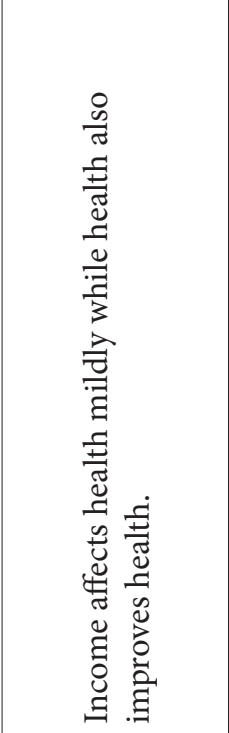 & 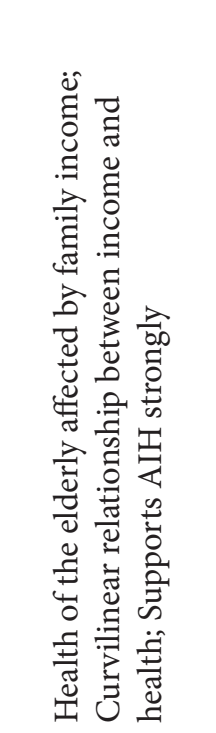 \\
\hline 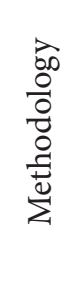 & $\tilde{0}$ & 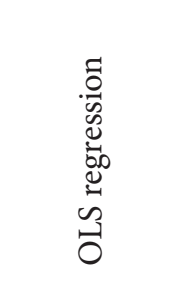 & 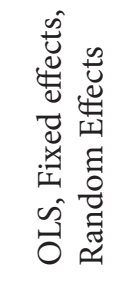 & 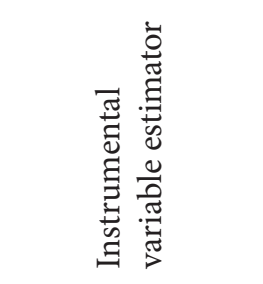 & 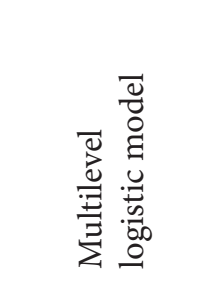 & 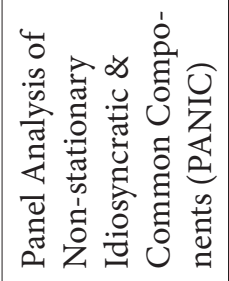 & 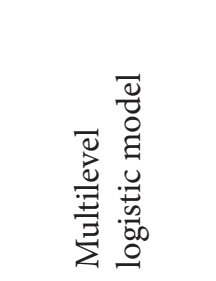 \\
\hline 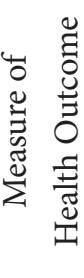 & 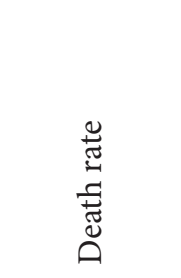 & 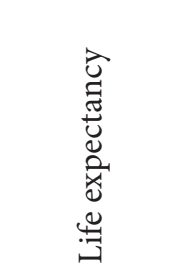 & 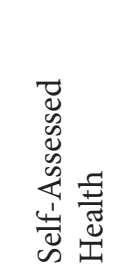 & 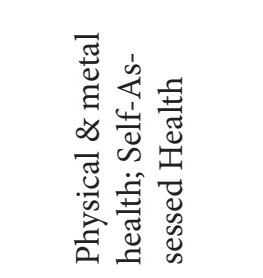 & 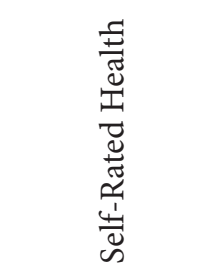 & 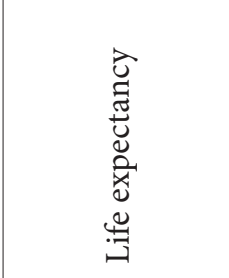 & 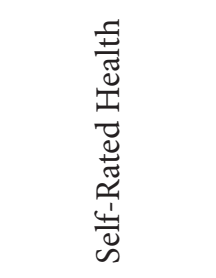 \\
\hline 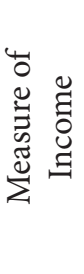 & 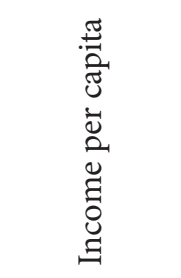 & 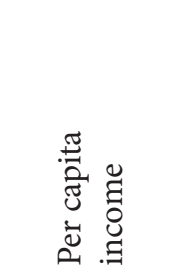 & 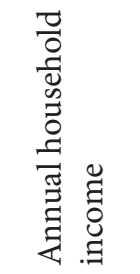 & 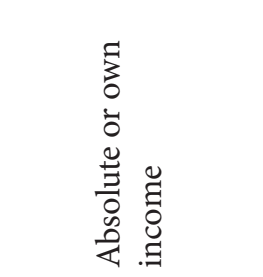 & 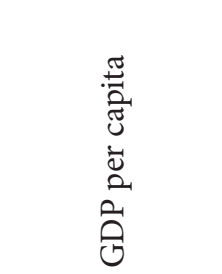 & 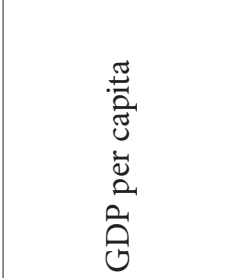 & 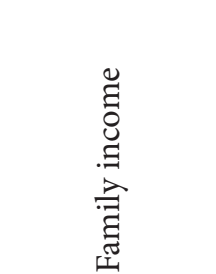 \\
\hline 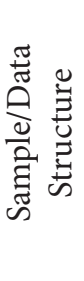 & 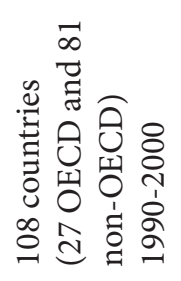 & 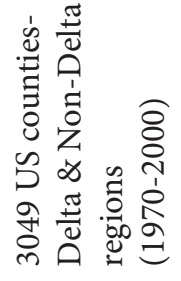 & 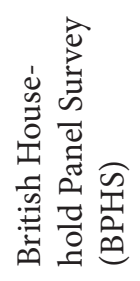 & 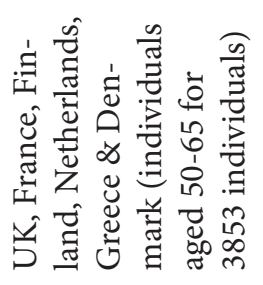 & 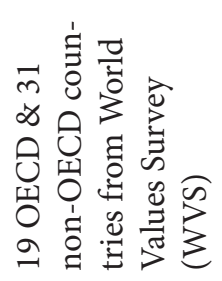 & 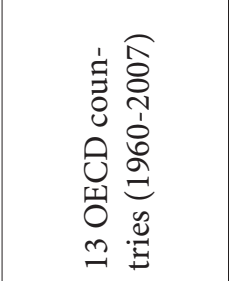 & 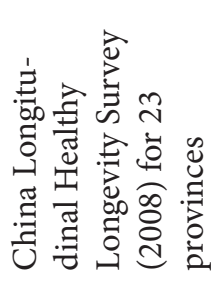 \\
\hline 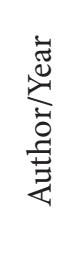 & 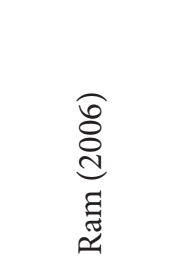 & 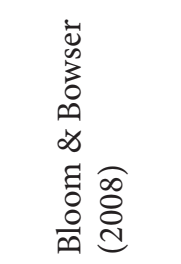 & 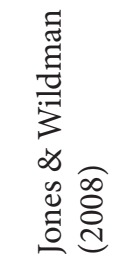 & 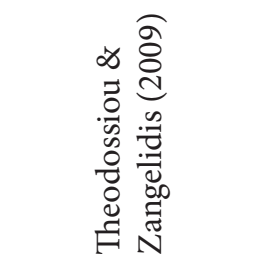 & $\begin{array}{l}\text { త্} \\
\text { d } \\
\ddot{a}\end{array}$ & 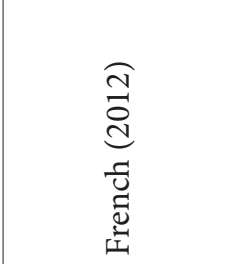 & 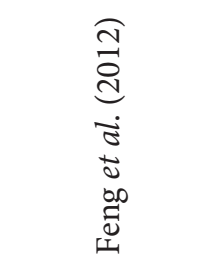 \\
\hline$\frac{k}{\omega}$ & $a$ & 으 & $=$ & $\simeq$ & $\stackrel{m}{=}$ & $\exists$ & $\stackrel{2}{\sim}$ \\
\hline
\end{tabular}




\begin{tabular}{|c|c|c|c|c|c|c|}
\hline 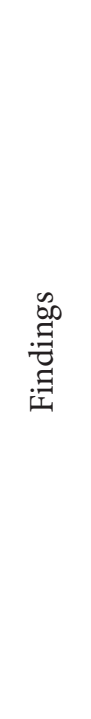 & 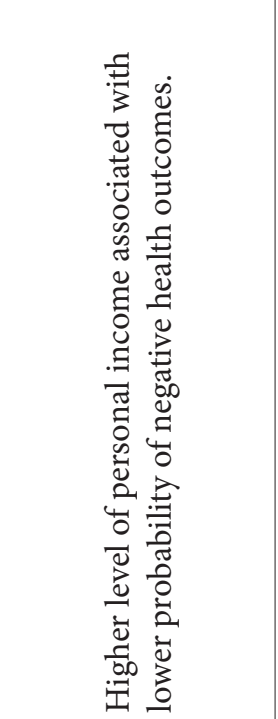 & 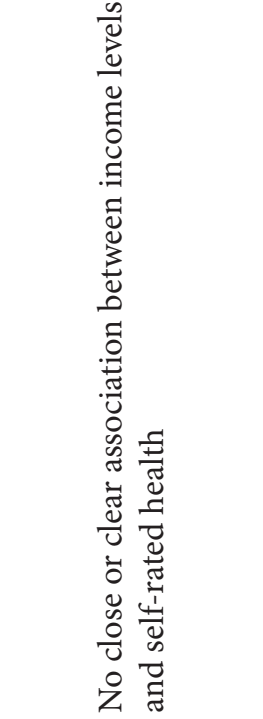 & 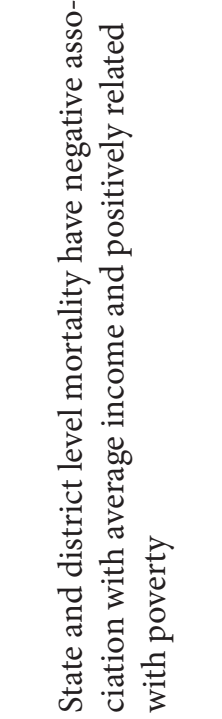 & 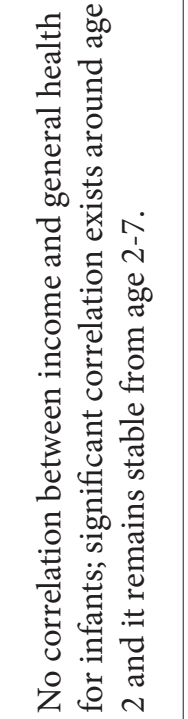 & 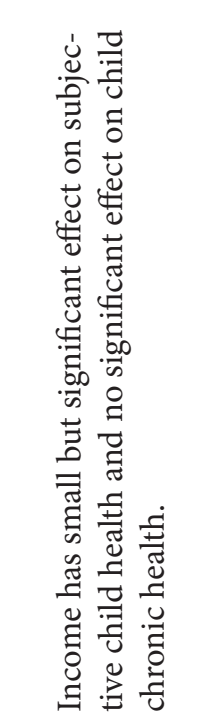 & 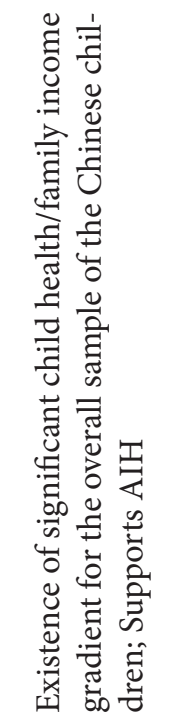 \\
\hline 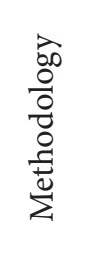 & 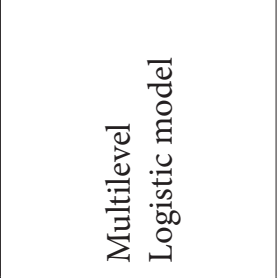 & 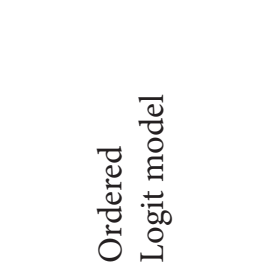 & 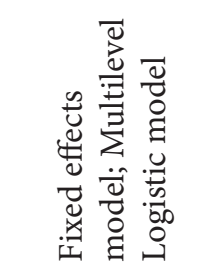 & 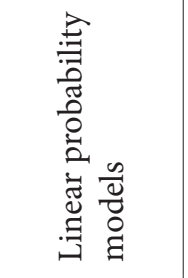 & 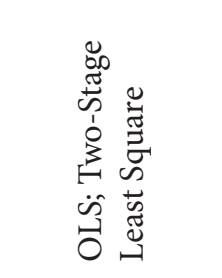 & 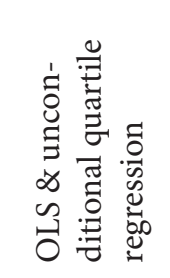 \\
\hline 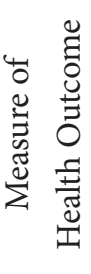 & 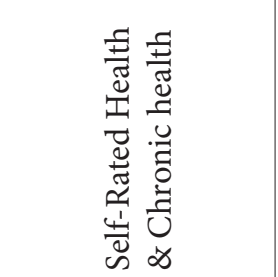 & 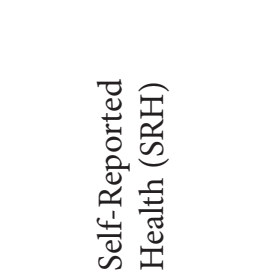 & 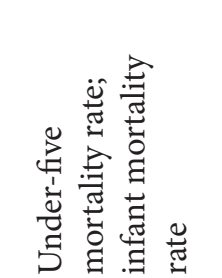 & 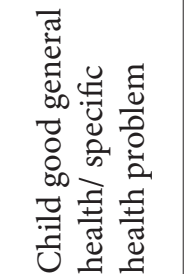 & 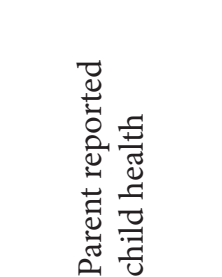 & 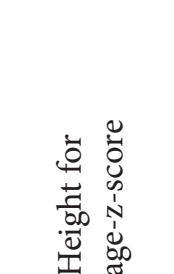 \\
\hline 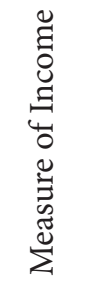 & 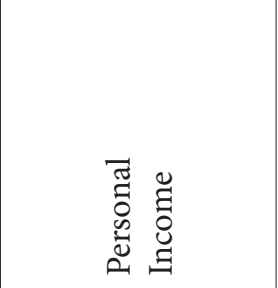 & 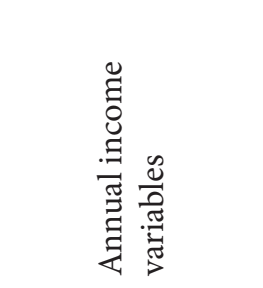 & 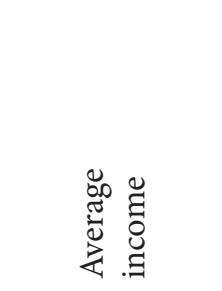 & 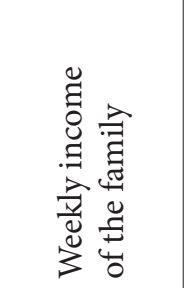 & 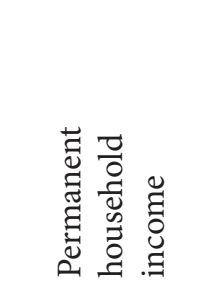 & 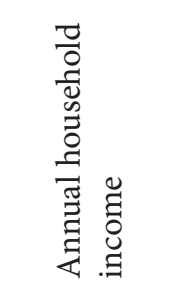 \\
\hline 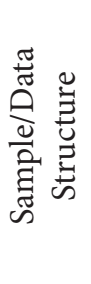 & 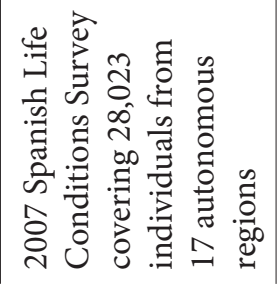 & 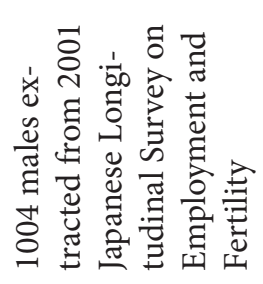 & 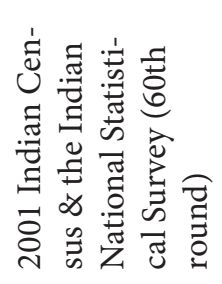 & 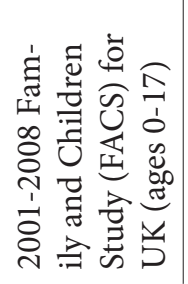 & 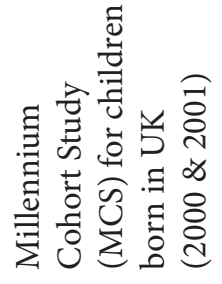 & 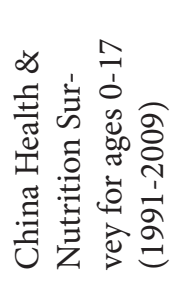 \\
\hline 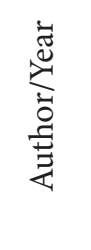 & 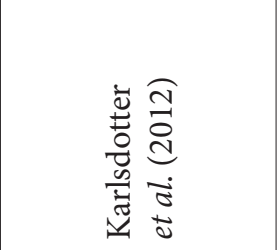 & 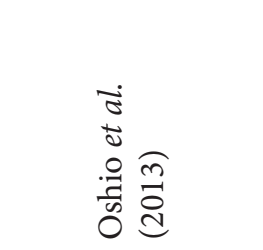 & 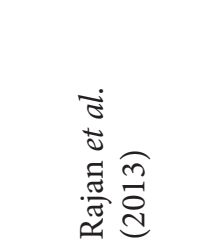 & 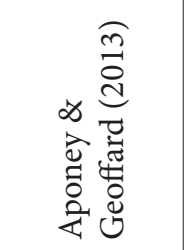 & 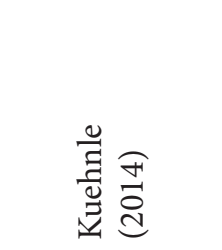 & 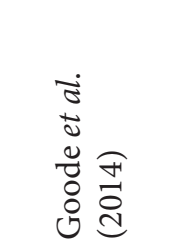 \\
\hline$\frac{z}{\infty}$ & 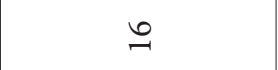 & 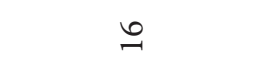 & $\triangleq$ & $\stackrel{\infty}{=}$ & - & $\sim$ \\
\hline
\end{tabular}




\begin{tabular}{|c|c|c|c|c|}
\hline 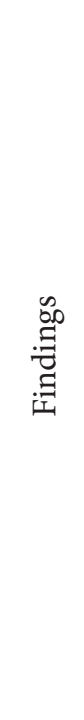 & 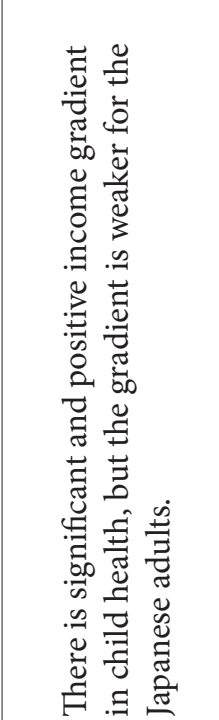 & 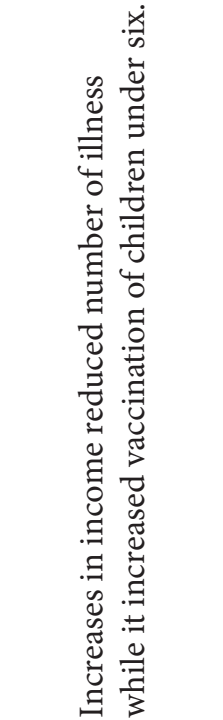 & 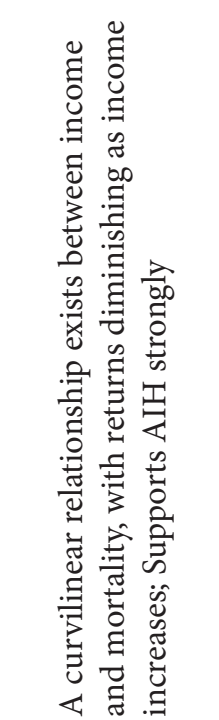 & 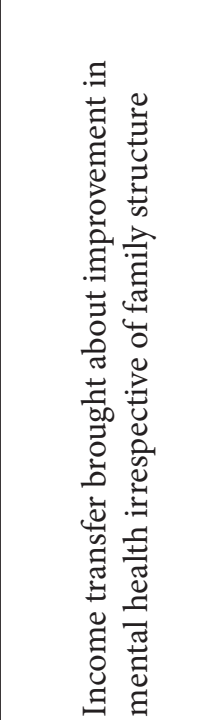 \\
\hline 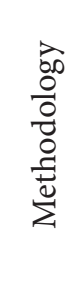 & 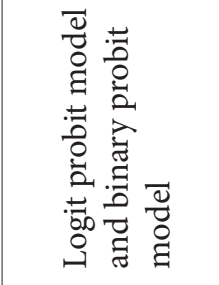 & 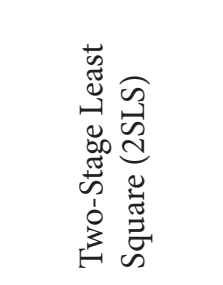 & 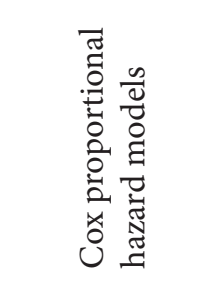 & 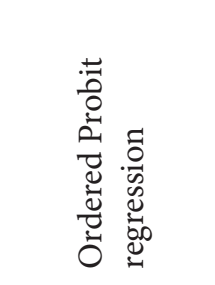 \\
\hline 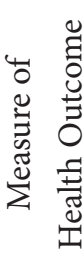 & 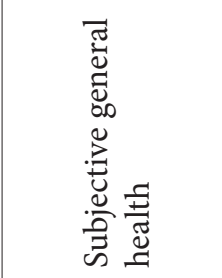 & 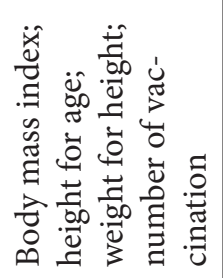 & 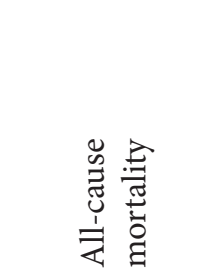 & 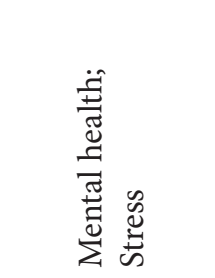 \\
\hline 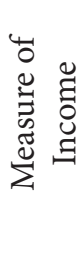 & 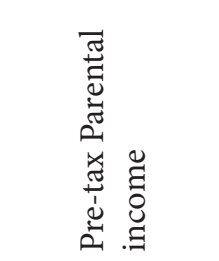 & 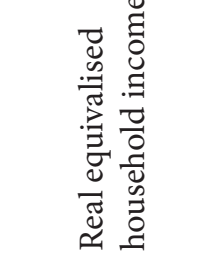 & 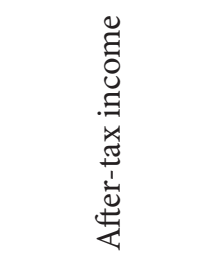 & 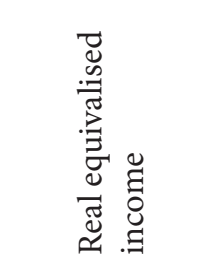 \\
\hline 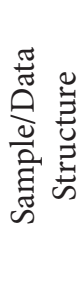 & 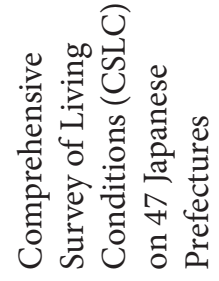 & 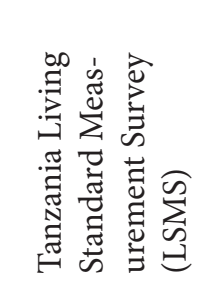 & 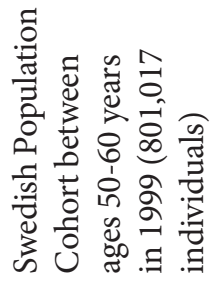 & 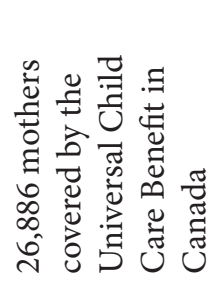 \\
\hline 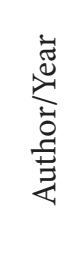 & 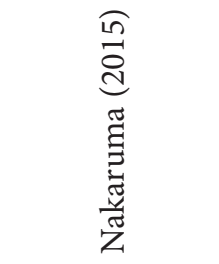 & 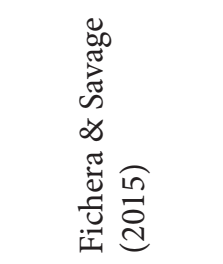 & 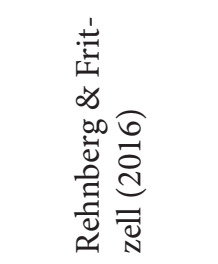 & 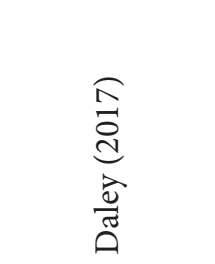 \\
\hline$\frac{z}{\infty}$ & $\vec{\sim}$ & $\tilde{\sim}$ & $\sim$ & $\stackrel{J}{\sim}$ \\
\hline
\end{tabular}




\section{DATA AND METHODOLOGY}

\section{The Data}

Data on under-five mortality rate and real per capita income are taken from World Development Indicators (WDI) online database of the World Bank while data on proportion of the population having access to improved sanitation were sourced from United Nations Millennium Development Goals (UN-MDGs) Indicators database. Data on real government health expenditure per capita are from World Health Organization (WHO) Global Health Observatory Data Repository. The extracted data covered the period of 2000-2012 for 34 Sub-Sahara African countries (see Table 1).

\begin{tabular}{ll}
\hline Sub-Region & Countries \\
\hline West Africa & $\begin{array}{l}\text { Benin, Burkina Faso, Cote d'Ivoire, Gambia, Ghana, Guinea, Guinea-Bissau, Mali, } \\
\text { Mauritania, Niger, Nigeria, Senegal, Sierra Leone and Togo }\end{array}$ \\
\hline Eastern Africa & $\begin{array}{l}\text { Burundi, Ethiopia, Kenya, Madagascar, Malawi, Mauritius, Mozambique, Uganda, } \\
\text { United Republic of Tanzania and Zambia }\end{array}$ \\
\hline Central Africa & Angola, Cameroon, Central African Republic, Chad, Congo and Gabon \\
\hline Southern Africa & Botswana, Lesotho, Namibia and South Africa \\
\hline
\end{tabular}

Table 2. List of Sampled Sub-Sahara African Countries

Source: Authors' compilation

\section{Empirical Model}

In the context of this study, we specify a heterogeneous model set-up based on the variables considered by previous studies (Feng, Wang, Jones, and Li, 2012; Qi, 2012). This is expressed as:

$$
U M_{i t}=\delta_{i}^{\prime} P Y_{i t}+\lambda_{i}^{\prime} P Y^{2}{ }_{i t}+\theta_{i}^{\prime} S N_{i t}+\varphi_{i} H Y_{i t}+w_{i t}
$$

where $i=1,2, \ldots, N ; t=1,2, \ldots, T$; UM is under-five mortality rate; PY is real per capita income; $\mathrm{PY}^{2}$ is squared per capita income as a proxy for concavity relationship between health and income; and the other considered control variables are proportion of population having access to improved sanitation $(\mathrm{SN})$, and real government health expenditure per capita (HY). The control variables- per capita health care expenditure and the proportion of population using improved sanitation are core determinants of health outcomes, especially in low-income regions (Lee et al, 2013; Odusanya, and Akinlo, 2015). Access to sanitation and health care expenditure are important complement to income. The composite unobservable error structure $\left(w_{i t}\right)$ is modelled as combination of individual specific effects $\left(\alpha_{i}\right)$, unobservable common factors $\left(f_{t}\right)$ with heterogeneous factor loadings $\left(\eta_{i}\right)$, and finite error term $\left(v_{i t}\right)$ as:

$$
w_{i t}=\alpha_{i}+\eta_{i}^{\prime} f_{t}+v_{i t}
$$

Eq. (2) accounts for unobservable risk factors that explains the variation in health status (UM) such as regional concentration of diseases (such as malaria and polio) induced by proximity of boarders in Africa. Similar factor model was adopted by Baltagi and Moscone (2010) within the context of explaining 
unobservable risk factors for health spending variation in OECD. The incorporated parameters for the observable $\left(\delta_{i}, \lambda_{i}, \theta_{i}, \phi_{i}\right)$ and unobservable $\left(\eta_{i}\right)$ follow a random coefficient structure that combines a common slope vector $(k)$ and country-specific random term $\left(\varepsilon_{i}\right)$.

$$
k_{i}=k+\varepsilon_{i}
$$

The key underlying properties of the specified heterogeneous model set-up (1-3) as extensively discussed in Pesaran (2006), Bond and Eberhardt (2009) and Eberhardt \& Teal (2012) are parameters heterogeneity, non-stationarity potentials of the observable and unobservable series, cross-section dependence, and endogeneity.

Hypothetically, all the explanatory variables excluding PY2 are expected to have negative effect on under-five mortality rate. AIH holds if PY is negative and significant as a necessary condition. Sufficiently, PY2 must be positive and significant to reflect the concavity of the nexus.

\section{Methods}

Pesaran and Smith (1995) Mean Group (MG) estimator, Common Correlated Effects Mean Group (CCEMG) estimator by Pesaran (2006), and the Augmented Mean Group (AMG) estimator by Eberhardt and Teal (2012) and Bond and Eberhardt (2009) are considered for estimating Eq.(1). Discussions on additional diagnostics test are in the next section.

\section{RESULTS AND DISCUSSION}

The preliminary analyses conducted using the standard panel data estimators (FE and RE) confirms the validity of AIH for SSA countries. After rejecting the Hausman test in favour of FE model, additional robustness tests revealed the sensitivity of the model to heterogeneity, non-stationarity and cross-sectional dependence. The validity of AIH collapses for SSA when the FE model is estimated with observable variables at logarithm level and robust standard error-(to control for serial correlation and heterokedasticity).

The under-five mortality rate (UM) variable rejects the null hypothesis of non-stationarity at level. But, the other observable variables (PY, $\mathrm{PY}^{2}, \mathrm{SN}$ and $\mathrm{HY}$ ) are found to be non-stationary at level and cross-sectionally correlated as shown on Table 2 . The evidence of non-stationarity and cross-section dependence of the observable and unobservable series challenges the standard panel data estimators' biasness and consistency attributes for validating the AIH for SSA.

\begin{tabular}{|c|c|c|c|c|c|c|c|c|c|}
\hline & \multicolumn{3}{|c|}{ Summary Statistics } & \multicolumn{2}{|c|}{ Pesaran (2004) CD } & \multicolumn{2}{|c|}{ PURT at level } & \multicolumn{2}{|c|}{ PURT at FD } \\
\hline & Obs & Mean & Std. Dev. & CD-Test & $|\overline{\hat{\rho}}|$ & MW & CIPS & MW & CIPS \\
\hline UM & 544 & 98.9 & 39.1 & $92.1^{*}$ & 0.972 & $700.7^{*}$ & $-2.80^{*}$ & $133.7^{\star}$ & $-2.35^{*}$ \\
\hline PY & 544 & 1814.3 & 2358.8 & $58.0^{*}$ & 0.704 & 56.0 & 0.92 & $189.5^{*}$ & $-1.57^{*}$ \\
\hline $\mathbf{P Y}^{2}$ & 544 & 8845259 & $2.05 \mathrm{E}+07$ & $58.1^{*}$ & 0.703 & 42.3 & 1.34 & $168.4^{*}$ & $-6.62^{*}$ \\
\hline SN & 544 & 29.6 & 18.8 & $70.7^{\star}$ & 0.918 & 29.3 & $-7.24^{\star}$ & $338.5^{*}$ & $-3.94^{*}$ \\
\hline HY & 544 & 203.8 & 239.7 & $54.1^{\star}$ & 0.638 & 73.9 & -0.34 & $214.3^{*}$ & $-2.67^{*}$ \\
\hline
\end{tabular}


Note: ${ }^{*}$ denotes significance at $1 \%$ critical level; $\mathrm{CD}=$ Cross-section Dependence; $|\overline{\hat{\rho}}|=$ average absolute value of the off-diagonal elements of the cross-sectional correlation matrix of the series; PURT = Panel Unit Root Test with the null hypothesis series is I(1). PURT was estimated at lag 1 and first order serial correlation was considered for the CIPS test; FD = First Difference; MW = Maddala \& Wu (1999) Fisher's PURT chi-square value; CIPS = Cross-sectionally augmented Im, Pesaran, and Shin (IPS) PURT Z(t-bar).

Table 3. Data Summary and Properties

Source: Authors' Computation from Stata 12

\begin{tabular}{|c|c|c|c|c|c|c|}
\hline $\begin{array}{c}\text { Dependent } \\
\text { Variable }\end{array}$ & \multicolumn{3}{|c|}{ Without Trend } & \multicolumn{3}{|c|}{ With Trend } \\
\hline Method & MG & CCEMG & AMG & MG & CCEMG & AMG \\
\hline Model & 1 & 2 & 3 & 4 & 5 & 6 \\
\hline \multirow{2}{*}{ PY } & $-0.4705^{\star}$ & -0.0648 & -0.0078 & $-0.3053^{\star}$ & -0.0529 & -0.0029 \\
\hline & $(-3.17)$ & $(-1.00)$ & $(-0.14)$ & $(-3.03)$ & $(-0.86)$ & $(-0.08)$ \\
\hline \multirow[t]{2}{*}{ PY2 } & $0.0002^{*}$ & 0.00003 & 0.00003 & $0.0002^{\star *}$ & 0.00005 & 0.00001 \\
\hline & $(2.63)$ & $(0.89)$ & $(0.85)$ & $(2.35)$ & $(1.26)$ & $(-0.20)$ \\
\hline \multirow[t]{2}{*}{ SN } & $-6.2499^{*}$ & 0.1379 & $-0.3099^{\star * *}$ & $-0.7789^{\star *}$ & -0.0362 & -0.2816 \\
\hline & $(-5.61)$ & $(0.71)$ & $(-1.76)$ & $(-2.15)$ & $(-0.23)$ & $(-1.64)$ \\
\hline \multirow[t]{2}{*}{$\mathrm{HY}$} & $-0.0346^{* * *}$ & 0.0066 & -0.0021 & 0.0039 & 0.0068 & 0.0025 \\
\hline & $(-1.73)$ & $(1.04)$ & $(-0.21)$ & $(0.22)$ & (1.08) & $(0.68)$ \\
\hline RMSE & 3.3990 & 0.6014 & 1.0614 & 1.4074 & 0.4875 & 0.6796 \\
\hline $\mathrm{CD}$ test & $13.27^{\star}$ & $-1.73^{* * *}$ & -0.89 & $2.64^{*}$ & -0.85 & 0.19 \\
\hline$|\overline{\hat{\rho}}|$ & 0.140 & -0.018 & -0.009 & 0.028 & -0.009 & 0.002 \\
\hline CIPS test & $-7.547^{\star}$ & $-5.082^{\star}$ & $-3.972^{\star}$ & $-7.911^{\star}$ & $-7.433^{\star}$ & $-5.071^{\star}$ \\
\hline Observation & 544 & 544 & 544 & 544 & 544 & 544 \\
\hline $\mathrm{N}$ & 34 & 34 & 34 & 34 & 34 & 34 \\
\hline
\end{tabular}

${ }^{*},{ }^{* *}$ and ${ }^{* * *}$ denote significance at $1 \%, 5 \%$ and $10 \%$ critical level respectively; Model 1-6 estimated with a constant term; $\mathrm{z}$-statistic shown in parentheses; RMSE = Root Mean Square Error; Pesaran's CD test p-values; Constant deterministic model with three lags and first-order serial correlation estimated for the CIPS test; the values reported for the CIPS test are Z ( $\mathrm{t}$-bar); $\mathrm{N}$ = Number of SSA countries; and the standard errors are robust to outliers.

Table 4: Heterogeneous Slopes Models

Source: Authors' Computation from Stata 12

The results of the heterogeneous slopes estimators with and without group-specific trends are shown on Table 3. Out of all the heterogeneous models, it is only MG estimates of real per capita income and its squared have the expected signs and statistically significant (Table 3 column 1 and 4). The evidence from MG model supports the validity of AIH for SSA. However, the significance disappears when the other robust heterogeneous estimators (CCEMG and AMG) accounted for cross-sectional dependence. Comparing the post-estimation diagnostic test results (such as RMSE, CD test, and absolute crosssection correlation [| $\overline{\hat{\rho}} \mid]$ ) show that the MG estimator performs poorly.

Based on the inconsistent results, we have no sufficient evidence to support the AIH for SSA (in the presence of cross-sectional dependence). Our evidence from the cross-sectional correlation cor- 
rected heterogeneous and non-stationary estimators (CCEMG and AMG) contradicts ${ }^{2}$ previous studies such as Qi (2012) and Ram (2006) that pooled few selected Africa countries with other developing and developed nations. The difference in our empirical outcomes with previous studies emanate from the adopted methods of estimation and their underlying attributes relating to slopes heterogeneity, observable and non-observable non-stationarity and cross-section dependence.

Lastly, we are able to establish a long-run relationship between income and health based on the CIPS test results on Table 3.

\section{CONCLUSION}

This study has clearly shown that modelling country-specific observable and unobservable heterogeneity and cross-section correlation, AIH validity disappears for SSA. This questions the empirical outcomes of previous studies that employed homogenous slopes model set-up. The analyses further revealed that income is not a significant determinant of reducing under-five mortality as a measure of health status improvement in SSA. This could be due to high poverty prevalence rate, wide income inequality gap and high deprivation rate of health facilities that heterogeneously engulfed SSA countries compared to other developed and developing countries where the AIH is valid. Consequently, it implies that the wealthier seems to be the healthier in SSA as increases in income tend to be associated with improvement in health. Therefore, the AIH cannot be confirmed for the SSA region based on the data and the methodology adopted. However, health spending per capita and improved sanitation that are purely non-income determinants are found to be core drivers of health outcome in SSA countries.

Since access to sanitation and health care expenditure (aside from income) have been established to be contributing significantly to the diminution in mortality, it becomes imperative for the government to set out policies that will improve its spending on health and access to improved sanitation. This is achievable via quality health infrastructure and specific health intervention programmes among inhabitants of the region. This will indeed complement the effect of higher income on healthy living in the region.

\section{REFERENCES}

Ando, T., \& Bai, J. (2016). Panel data models with grouped factor structure under unknown group membership. Journal of Applied Econometrics, 31(1), 163-191. DOI: 10.1002/jae.2467

Apouey, B., \& Geoffard, P. (2013). Family income and child health in the UK. Journal of Health Economics, 32(4), 715-727. DOI: 10.1016/j.jhealeco.2013.03.006

Baltagi, B., \& Moscone, F. (2010). Health care expenditure and income in the OECD reconsidered: Evidence from panel data. Economic Modelling, 27(4), 804-811. DOI: 10.1016/j.econmod.2009.12.001

Bloom, D., \& Bowser, D. D. (2008). The population health and income nexus in the Mississippi River Delta Region and beyond. Journal of Health and Human Services Administration, 31(1), 105-133

Bond, S. R., \& Eberhardt, M. (2009). Cross-section dependence in non-stationary panel models: A novel estimato. Retrieved April 23, 2017, from https://mpra.ub.uni-muenchen.de/17870/2/MPRA_paper_17870.pdf

Contoyannis, P. Jones, A. M., \& Rice, N. (2004). The dynamics of health in the British household panel survey. Journal of Applied Econometrics, 19(4), 453-503. DOI: 10.1002/jae.755

Daley, A. (2017). Income and mental health of Canadian mothers: Evidence from Universal Child Care Benefit. SSM-Population Health, 3, 674-683. DOI: 10.1016/j.ssmph.2017.08.002

2 The heterogeneous and non-stationary based estimator, MG, support the AIH for SSA. But it performs poorly compared to other set of estimators (CCEMG and AMG) that does not assume cross-sectional independence across SSA countries. 
Eberhardt, M., \& Presbitero, A. F. (2015). Public debt and growth: Heterogeneity and non-linearity. Journal of International Economics, 97(1), 45-58. DOI: 10.1016/j.jinteco.2015.04.005

Eberhardt, M., \& Teal, F. (2012). Productivity analysis in global manufacturing production. Retrieved April 23, 2017, from https://www.economics.ox.ac.uk/materials/papers/4729/paper515.pdf

Ecob, R., \& Smith, G.D. (1999). Income and health: What is the nature of the relationship? Social Science and Medicine, 48(5), 693-705

Feng, Z, Wang, W. W., Jones, K., \& Li, Y. (2012). An exploratory multilevel analysis of income, income inequality and self-rated health of the elderly in China. Social Science \& Medicine, 75(12), 2481-2492. DOI: 10.1016/j. socimed.2012.09.028

Fichera, E., \& Savage, D. (2015). Income and health in Tanzania: An instrumental variable approach. World Development, 66, 500-515. DOI: 10.1016/j.worlddev.2014.09.016

French, D. (2012). Causation between health and income: A need to panic. Empirical Economics, 42(2), 583-601. DOI: $10.1007 / \mathrm{s} 00181-001-0541-5$

Goode, A., Mavromaras, K., \& Zhu, R. (2014). Family income and child health in China. China Economic Review, 29, 152-165. DOI: 10.1016/j.chieco.2014.04.007

Gravelle, H., Wildman, J., \& Sutton, M. (2002). Income, income inequality and health: What can we learn from aggregate data? Social Science \& Medicine, 54(4), 577-589. DOI: 10.1016/S0277-9536(01)00053-3

Grossman, M. (1972). On the concept of health capital and the demand for health. The Journal of Political Economy, 80(2), 223-255

Jones, A.M., \& Wildman, J. (2008). Health, income and relative deprivation: Evidence from the BHPS. Journal of Health Economics, 27(2), 308-324. DOI: 10.1016/j.jheaeco.2007.05.007

Jusot, F. (2006). The shape of the relationship between mortality and income in France. Annals D'economie Et De Statistique, 83(84), 90-121

Karlsdotter, K., Martin, J.J., \& Gonzalez, L.A. (2012). Multilevel analysis of income, income inequalities and health in Spain. Social Science \& Medicine, 74(7), 1099-1106. DOI: 10.1016/j.socscimed.2011.020

Kuehnle, D. (2014). The causal effect of family income on child health in the UK. Journal of Health Economics, 36, 137-150. DOI: 10.1016/j.jhealeco.2014.03.011

Lee, S., Lim, J., Lee, H., \& Park, C. (2013). Food prices and population health in developing countries: An investigation of the effects of the food crisis using a panel analysis. Manila, Philippines: Asian Development Bank.

Li, H., \& Zhu, Y. (2006). Income, income inequality, and health: Evidence from China. Journal of Comparative Economics, 34(4), 668-693. DOI: 10.1016/j.rssm.2012.07.002

Nakaruma, S. (2014). Parental income and child health in Japan. Journal of Japanese and International Economics, 32, 42-55. DOI: 10.1016/j.jjie.2013.12.003

Odusanya, I. A., \& Akinlo, A. E. (2015). Income and Health Nexus in Sub-Saharan Africa. A test of the Absolute Income Hypothesis. Journal of Demography and Social Studies, 2 (1\&2), 1-10

Omran, A. (2005).The epidemiological transition: A theory of the epidemiology of population change. The Milbank Quarterly, 83(4), 731-757. DOI:10.1111/j.1468-0009.2005.00398.x

Oshio, T., Umeda, M., \& Fujji, M. (2013). The association of life satisfaction and self-rated with income dynamics among male employees in Japan. Japan and the World Economy, 28, 143-150. DOI: 10.1016/j.japwor.2013.09.003

Pesaran, M. H. (2006). Estimation and inference in large heterogeneous panels with a multifactor error structure. Econometrica, 74(4), 967-1012

Pesaran, M. H., \& Smith, R. (1995). Estimating long-run relationships from dynamic heterogeneous panels. Journal of Econometrics, 68(1), 79-113. DOI: 10.1016/0304-4076(94)01644-F

Pritchett, L., \& Summers, L. H. (1996). Wealthier is healthier. The Journal of Human Resources, 31(4), 841-868. DOI: $10.2307 / 146149$ 
Preston, S. H. (1975). The changing relation between mortality and level of economic development. Population studies, 29(2), 231-248

Qi, Y. (2012). The impact of income inequality on self-rated general health: Evidence from a cross-national study. Research in Social Stratification and Mobility, 30(4), 451-471. DOI: 10.1016/j.jce.2006.08.005

Rajan, K., Kennedy, J., \& King, L. (2013). Is wealthier always healthier in poor countries? The health implications of income, inequality, poverty, and literacy in India. Social Science \& Medicine, 88, 98-107. DOI: 10.1016/j. socscimed.2013.04.004

Ram, R. (2005). Income inequality, poverty, and population health: Evidence from recent data for the United States. Social Science \& Medicine, 61(12), 2568-2576. DOI: 10.1016/j.socscimed.2005.04.083

Ram, R. (2006). Further examination of the cross-country association between income inequality and population health. Social Science \& Medicine, 62(3), 779-791. DOI: 10.1016//j.socscimed.2005.06.034

Reinberg, J., \& Fritzell, J. (2016). The shape of association between income and mortality in old age: A longitudinal Swedish national register study. SSM-Population Health, 2, 750-756. DOI: 10.1016/j.ssmph.2016.10.005

Safaei, J. (2007). Income and health inequality across Canadian provinces. Health and Place 13(3), 629-638. DOI: 10.1016/j.healtplace.2006.09.003

Theodossiou, I., \& Zangalidis, A. (2009). The social gradient in health: The effect of absolute income and subjective social status assessment on the individual's health in Europe. Economics and Human Biology, 7(2), 229-237. DOI: 10.1016/j.ehb.2009.05.001

Wen, M. Browning, C. R., \& Cagney, K. A. (2003). Poverty, affluence, and income inequality: Neighbourhood economic structure and its implications for health. Social Science and Medicine 57(5), 843-860

WHO. (2014). Global Health Observatory Data Repository. Retrieved April 23, 2017, from World Health Organisation http://apps.who.int/gho/data

World Bank. (2015). World Development Indicators. Retrieved April 23, 2017, from World Bank http://data. worldbank.org/data-catalog/world-development-indicators

\section{POVEZANOST DOHOTKA I ZDRAVLJA POJEDINCA U PODSAHARSKOJ AFRICI: DOKAZI NA OSNOVU MODELA HETEROGENOG PANELA}

Rezime:

Istraživanje predočeno u ovom radu predstavlja pokušaj da se ispita odnos između dohotka i zdravlja pojedinca primenom AIH hipoteze (Absolute Income-Health Hypothesis, hipozete o odnosu apsolutnog dohotka i zdravlja). Ispitivanje je prvenstveno usredsređeno na 34 podsaharske zemlje u periodu od 2001-2016. Podaci za studiju su uglavnom preuzeti iz baze Indikatora svetskog razvoja (WDI) i repozitorijuma podataka o globalnom javnom zdravlju Svetske zdravstvene organizacije (ZSO). Korišćenjem postavke heretogenih slopova koja uključuje seriju nestacionarnih, unakrsno zavisnih i grupno specifičnih trendova, nismo uspeli da pronađemo dokaze koji bi potkrepili AIH hipotezu. Naš empirijski ishod podstakao je sumnju na robustnost prethodnih studija koje su ignorisale takve atribute modeliranja, a dovodi nas do zaključka da je metodologija zaista važna u analizi povezanosti zarade pojedinca i njegovog zdravlja, kao i u testiranju validnosti AIH hipoteze za presek zemalja. Nasuprot tome, smatramo da prihodi predstavljaju beznačajnu determinantu zdravlja u podsaharskoj Africi u poređenju sa potrošnjom u zdravstvu i pobolǰ̌anom sanitacijom.
Ključne reči:

zdravlje, dohodak, podsaharska Afrika, heterogeni nagib, unakrsna zavisnost 